\title{
A Comparison Study of Learner Autonomy and Language Learning Strategies among Thai EFL Learners
}

\author{
Tirada Iamudom
}

Language Institute, Thammasat University, Thailand, iam.tirada@hotmail.com

\section{Supong Tangkiengsirisin}

Language Institute, Thammasat University, Thailand, supong_tu@yahoo.com

Learner autonomy is a way to promote students to perform their learning ability effectively and it is essential for students to acquire this skill for a lifelong learning journey. The present study aimed to investigate the learner autonomy level and observe in detail language learning strategies use of Thai EFL learners comparing international school students and Thai public-school students in a tutorial school in Bangkok. 200 senior high school level students, 100 international school students and 100 Thai public-school students, in a tutorial school participated in the study. The study design is mix-method research. A learner autonomy questionnaire and the Strategy Inventory for Language Learning (SILL) questionnaire by Oxford (1990) were the quantitative data collection instruments in this study. Interviews were conducted for more information in detail as qualitative data collection. The data analysis was carried out through quantitative analysis techniques. The findings from the learner autonomy questionnaires revealed that Thai public school students have a higher level of learner autonomy. Moreover, the findings from the SILL questionnaires also showed that Thai public school students employ language learning strategies more than the international school students. The cognitive strategies are mostly employed by the international school students whereas the compensation strategies are widely used by Thai public school students.

Keywords: autonomous learning, language learning strategies, learner autonomy, Thai EFL learners, EFL

\section{INTRODUCTION}

English learning autonomy and language learning strategies are the key dimensions in learners' English performance. For Thai learners, the empirical research reveals that even if Thai students learn English when they are very young, they do not improve English proficiency when they grow up, especially in communicating with the foreigners (Lightbown \& Spada, 2013). Thai society encourages the children to learn as much as

Citation: Iamudom, T., \& Tangkiengsirisin, S. (2020). A Comparison Study of Learner Autonomy and Language Learning Strategies among Thai EFL Learners. International Journal of Instruction, 13(2), 199-212. https://doi.org/10.29333/iji.2020.13214a 
possible, which lead to many educational problems as shown nowadays; the increment of stressfulness among children, the lack of an outstanding talent in children and so on. So, to promote the learners to become an autonomous learner can encourage them when they finished the school and have to learn by themselves. They will know what they should learn and how to learn appropriately and efficiently. One of the stimulating factors for encouraging the learners' learning process is learning strategies. In the classroom settings, there are one or more than two teachers to assist learners process their learning, in contrast, outside the classroom, learners will have no one to tell what they have to do next or deal with the unexpected problems. Therefore, to allow learners to acquire appropriate strategies in learning can enhance their opportunity to learn by themselves alone, and also in the long term profit.

As many empirical studies have been conducted in terms of learner autonomy issues and language learning strategies used by language learners, this study aims to observe the influence of language learning strategies on the autonomy of language learners. As Wong (2005) said that with high self-efficacy, it can promote the LLS use among learners. And, Du (2012) bears out Wong's finding that cognitive strategies have correlated with the self-efficacy of learners. Also, with the findings of Nosratina et al. (2014), they found that metacognitive strategies affect self-efficacy of EFL learners. The studies mentioned previously were conducted at the university student level outside Thailand. In addition, many research studies have been conducted to investigate the autonomy learning readiness of Thai students such as Swatevacharkul (2008), and Thai teachers and students such as Tayjasanant and Suraratdecha (2016). Both of them found that there were some obstacles which blocked the development of autonomy among Thai learners. However, for Littlewood (1999), autonomy can be implemented with East Asian learners and teachers by learner training and appropriate learning environments. To Dickinson (1987), self-regulation models should be proposed to both the learners and teachers who are new to self-instruction. He stated more that to prepare the learners well with the necessary materials and resources available, they might benefit from the learner training program which would introduce them to use of learning strategies efficiently (Dickinson, 1987). Therefore, this study furthers the observation of learning autonomy among Thai EFL students, learning in international schools and Thai public school; the different use of learning strategies was also observed by formulating similar interview questions.

According to the mentioned statement above, this study has the objectives as following.

\section{Objective of the Study}

This study aims to:

1. investigate the level of learner autonomy of Thai EFL students learning in the international school and Thai public school

2. examine the differences of English learning strategies use of Thai EFL students learning in the international school and Thai public school

\section{Research Questions}

The research questions in this study are formulated as following: 
1. What is the level of English language learning autonomy of Thai EFL students learning in the international school and Thai public school?

2. What are the differences of English language learning strategies used by Thai EFL students learning in the international school and Thai public school?

\section{CONTEXT AND REVIEW OF LITERATURE}

\section{Learner Autonomy}

Schwartz (1977), as cited in Gardner (1981), stated in 'L'éducation demain' that 'autonomy' is "the ability to assume responsibility for one's own affairs". It is "the ability to take charge of one's learning" (Gardner, 1981:3). Gardner stated more that this 'ability' cannot be obtained innately, but it comes from formal systematic learning. Moreover, 'ability' to him cannot conduct 'behavior'; however, it is the power or capacity to do something. So, 'autonomy' is the ability to manipulate behavior in the given situation and 'learner autonomy' is an ability to conduct the learners' behavior in the learning process.

To Littlewood (1996), the term 'autonomy' is understood to refer to one particular kind of autonomy, namely, "learner autonomy". Here the term may refer to a capacity for thinking and acting independently that may occur in any kind of situation (including, of course, a situation where the focus is on learning). Scharle and Szabó (2000:4) define autonomy as "the freedom and ability to manage one's own affairs, which entails the right to make decisions as well." According to Scharle and Szabó (2000), the terms autonomy and responsibility are hard to distinguish. In order to foster learner autonomy, learners need to develop a sense of responsibility while taking an active role in making decisions about their learning. Benson (2011:58) defined 'autonomy' as "the capacity to take control of one's own learning". It is clearly shown that to have learner autonomy in language learning, 'responsibility' of learners is important. In the next part, the component of learner autonomy which enables language learners to have responsibility in their learning will be discussed.

\section{Components of Learner Autonomy}

To Wenden (1991) a learner who wants to have learner autonomy should have willingness and ability to take charge of their learning. Wenden stated that willingness and ability of a learner can be promoted by improving their (Wenden, 1991:52). Moreover, two attitudes provided to foster learner autonomy are 'willingness to take on responsibility' and 'confidence in their ability as learners' (Wenden, 1991). To Wenden, the students should be confident and trust in their ability to learn or monitor their own learning. Unless the learners are willing to take responsibility for their learning, their autonomy will not be developed (Borge and Al-Busaidi, 2012). The willingness to take on responsibility can be defined as the learners will do whatever to acquire the language learning as they "see themselves having a crucial role on their language learning" (Wenden, 1991:53).

To Littlewood (1996), the similar idea is presented as ability to acquire knowledge and skill, and willingness to have motivation and confidence in learning are the key term for 
the learners to develop their learner autonomy. This means to be a capable learner, knowledge and skill are required. Moreover, the learners should be motivated and confident in their ability to take responsibility in their learning process. To Littlewood (1996) learners who have ability to choose the knowledge and have the necessary skill to carry out whatever alternatives seem most appropriate are keen to have learner autonomy.

Furthermore, when learners need to learn language, they will have attitude to learn. Then, when they have a favourable attitude of language learning, they will have need or desire to learn it, which is called motivation. Obviously, motivation is also a vital part of learner autonomy. It can promote responsibility among learners and their capacity to be more confident in their ability to learn.

Therefore, it is obviously shown that learners' willingness to take on their responsibility and learners' confidence in their capacity under 'attitudes' can promote learner autonomy (Wenden, 1991). Moreover, this idea meets the same notion of Littlewood's that willingness to take their learning responsibility and ability to have knowledge and skill can encourage a learner to have more learner autonomy (Littlewood, 1996). Finally, to Lightbown and Spada (2013), a student who has positive attitudes, which originated from motivation, tends to have willingness to take responsibility in learning. The components of learner autonomy are illustrated graphically as following:

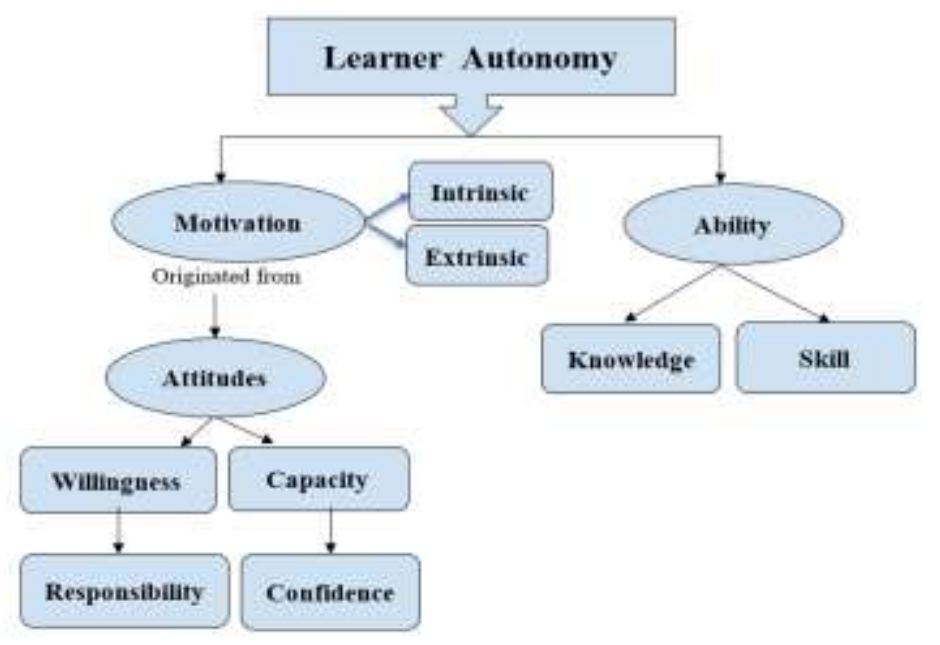

Figure 1

Components of Learner Autonomy

The 4 main components of learner autonomy mentioned earlier are the framework of this recent study. The participants are measured their level of willingness, selfconfidence, motivation, and capacity to learn by the questionnaires based on the 4 components. Next, the dimension of learner autonomy will be reviewed to expand the idea of how learner autonomy relates to the language learners. 


\section{Language Learning Strategies}

The term 'strategy' has been defined as: "a method, plan, or stratagem to achieve some goal" (New Webster's Dictionary of the English Language, 1974). The term 'learning strategies' are also defined by the researchers as: "an attempt to develop linguistic and sociolinguistic competence in the target language" (Tarone, 1980:419). Wenden and Rubin said that it is "strategies which contribute to the development of the language system which the learner constructs and affect learning directly" (Wenden and Rubin, 1987:23). Furthermore, LLS can help to encourage autonomy, and lifelong independence of learners, Little (1991).

According to Oxford (1990), six basic types of L2 learning strategies have been categorized; cognitive, memory, compensation, metacognitive, affective, and social strategies. The first three are direct strategies, which are closely related to the target language used to manipulate language learning strategies by language learners, and the latter three are indirect strategies, which support and manage language without being directly involved in the target language. It seems that both direct strategies and indirect strategies support each other.

Memory strategies are sometimes known as 'mnemonics'. Language learners use this kind of strategy to remember the words and recall them when they are needed to be used. Memory strategies enable learners to regain their knowledge as powerful mental tools (Oxford, 1990).

Cognitive strategies are the most popular strategies among language learners to manipulate their learning process and to gain language performance (Oxford, 1990). In addition, Mitchell (2014) defined cognitive strategies as the ways to assist language learners to acquire language skill by organizing and integrating information (Mitchell, 2014).

Many difficulties are found when learners learn language, and compensation strategies will help them to cope with those obstacles. Good language learners will use 'intelligent guessing' to propel their learning in a clever way.

Metacognitive are the strategies of how learner process their cognition in their learning (Oxford, 1990; 2003; 2017). O'Malley and Chamot stated that metacognitive strategies refer to the higher executive skills that may entail planning, monitoring, and selfevaluation, whereas cognitive strategies are more direct to individual learning task (O’Malley and Chamot, 1990). These kinds of strategies are also used to overview and self-direct language learning (Rubin, 1987).

The affective strategy is about how learners deal with their emotions, beliefs, attitudes, and motivation when learning language. This kind of learning strategy refers to the identification of one's mood and anxiety level, feeling towards the reward and good performance of L2 proficiency (Oxford, 2003).

The social strategy is about how learners convey language and communicate with others. This issue is also about the sociocultural context such as age, gender, sex, social level, and so on. To Chamot (1987), social strategies are the cooperative skill of language 
learners working with their peers or native speakers to deal with error and retain feedback, in order to improve their L2 proficiency. Thus, social strategies will underpin the interaction and communication activities.

\section{METHOD}

\section{Research Instrument}

To conduct the study, mix-method research is employed in the investigation. The learner autonomy questionnaire used in this study was adapted from MILLA questionnaire (Murase, 2015), learner autonomy cart sort (Cooker, 2015), and learner autonomy questionnaire (Joshi, 2011). The core concept of the learner autonomy questionnaire is based on the four components; students' willingness, students' self-confidence, students' motivation, and students' ability. Moreover, the Strategy Inventory for Language Learning (SILL), developed by Oxford (1990) was adapted to be used in this study. The results of the 5-point Likert scale questionnaire data were analysed by Descriptive Statistic in SPSS (IBM Version 23) to find the mean score and standard deviation (SD). In addition, a qualitative method is used to observe the LLS in depth. The retrospective interview was provided as an important tool to explore and elaborate the aspects of strategies use. The approximately 30 minutes semi-structured interview was provided to elicit participants' information about language learning strategies usage. The interview questions were divided into 6 questions, along the language learning strategies use. The result of six semi-structured interviews were content analysed by coding the reasons and some personal experience of the participants related to the questionnaire information each participant had provided previously.

\section{Participants}

The participants of this study were convenient sampling which come from the whole population of 387 senior high school students in a tutorial school in Bangkok. According to Yamane's (1967) sample calculation, more than 196 participants out of the population rounded up to 400 were selected as the participants in the study, with a sampling error less than or equal to 0.05 and reliability equal to $95 \% .200$ students out of 387 were divided into subgroup to be the participants of the study: 100 international school students, who had studied in the international school program since they were young and never attended a Thai public school; and 100 Thai public school students, who had never attended any international school program. All of them are in senior high school students. It is noted that bilingual and English program student in Thai public school are excluded due to the different factor of learning.

\section{Validation Process and Pilot Study}

Regarding to the validation, the learner autonomy questionnaire was sent to find its validity by three English language teaching experts to find the congruence between the study objectives and the questionnaire statements. Then, the obtained data was calculated using the Index of Item-Objective Congruence (IOC) (Rovinelli \& Hambleton, 1977) of each questionnaire statement. the content validity of the learner autonomy questionnaire, comprising of 23 items, was 0.83 . However, some statements 
were reviewed due to the comments of the experts. According to the quantitative reliability, the pilot study was conducted. The questionnaires were applied to 60 students; 30 international school students and 30 Thai public school students. After piloting the study of the two questionnaires, they were brought to calculate the reliability. The Cronbach Alpha of English version of learner autonomy questionnaire and language learning strategies questionnaire were 0.73 and 0.74 respectively, and for the Thai version of the learner autonomy questionnaire and language learning strategies questionnaire, 0.92 and 0.86 respectively.

\section{FINDINGS}

According to the research question 1: What is the level of English language learning autonomy used by Thai EFL students learning in the international school and Thai public school?

The analysed data shows that the grand mean $(\overline{\mathrm{X}})$ was 3.50 and the Standard Deviation (SD) was 0.55 for international school students and $\overline{\mathrm{X}} 3.76$ and SD 0.52 for Thai public school students. According to the criteria, the range from 3.41 to 4.20 suggests very high level of learner autonomy; therefore, on average, the level of learner autonomy of both group of participants was at the high level.

In order to obtain more information, the descriptive statistical analysis was conducted to further analyse each domain in the learner autonomy questionnaire. The result is presented in Table 1 with the interpretation of the level of learner autonomy.

Table 1

Mean of each Domain and Level of Learner Autonomy

\begin{tabular}{llll}
\hline Participants & & $\begin{array}{l}\text { Thai Public-School } \\
\text { Domain }\end{array}$ & $\begin{array}{l}\text { International School } \\
\text { Students }(\mathrm{n}=100)\end{array}$ \\
\hline Willingness & Mean $(\overline{\mathrm{X}})$ & 3.85 & 3.60 \\
& SD & 0.71 & 0.76 \\
& LA Level & High & High \\
\hline Self-confidence & Mean $(\overline{\mathrm{X}})$ & 3.75 & 3.49 \\
& SD & 0.62 & 0.76 \\
& LA Level & High & High \\
\hline Motivation & Mean $(\overline{\mathrm{X}})$ & 3.77 & 3.39 \\
& SD & 0.51 & 0.54 \\
& LA Level & High & Moderate \\
\hline Capacity & Mean $(\overline{\mathrm{X}})$ & 3.66 & 3.51 \\
& SD & 0.76 & 0.74 \\
& LA Level & High & High \\
\hline Total & Mean $(\overline{\mathrm{X}})$ & 3.76 & 3.50 \\
& SD & 0.52 & 0.55 \\
& LA Level & High & High \\
\hline
\end{tabular}

The table 1 displays that on average the Thai EFL learners in Thai public school had high levels of learner autonomy. Their willingness was at the highest level of all the domain $(\overline{\mathrm{X}}=3.85, \mathrm{SD}=0.71)$, followed by the motivation to learn language $(\overline{\mathrm{X}}=3.77$, 
$\mathrm{SD}=0.51)$. Besides, their self-confidence and capacity to learn autonomously were also at the high level $(\overline{\mathrm{X}}=3.75, \mathrm{SD} 0.62$ and $\overline{\mathrm{X}}=3.66, \mathrm{SD}=0.76$ respectively).

Table 1 also presents that on average the Thai EFL learners in international school had high level in every domains of learner autonomy except the motivational domain. Their willingness ranked the highest proportion $(\overline{\mathrm{X}}=3.60, \mathrm{SD}=0.76)$. Their capacity and self-confidence to learn autonomously were also high $(\overline{\mathrm{X}}=3.51, \mathrm{SD}=0.74$ and $\overline{\mathrm{X}}=$ $3.49, \mathrm{SD}=0.76$ respectively). From the table, motivation of the participants was in the lowest range; however, it was still in the high level $(\overline{\mathrm{X}}=3.51, \mathrm{SD}=0.74)$.

According to the research question 2: What are the differences of English language learning strategies used by Thai EFL students learning in the international school and Thai public school?

The analyzed data shows that the grand mean $(\overline{\mathrm{X}})$ was 3.58 and 3.42 and the Standard Deviation (SD) was 0.46 and 0.49 respectively. According to the criteria, the range from 3.41 to 4.20 suggests high level of language learning strategies use; therefore, on average, the level of language learning strategies use of the Thai EFL learners in Thai public school and international school was at the high level.

The result is presented in Table 2 with the interpretation of the level of language learning strategies use.

Table 2

Mean of Each Domain and Level of Language Learning Strategies Use

\begin{tabular}{|c|c|c|c|}
\hline \multicolumn{2}{|c|}{$\begin{array}{l}\text { Participants } \\
\text { Learning Strategies Domain }\end{array}$} & \multirow{2}{*}{$\begin{array}{l}\text { Thai Public-School } \\
\text { Students }(\mathrm{n}=100) \\
3.36\end{array}$} & \multirow{2}{*}{$\begin{array}{l}\text { International School } \\
\text { Students }(\mathrm{n}=100) \\
2.83\end{array}$} \\
\hline Memory Strategy & Mean $(\overline{\mathrm{X}})$ & & \\
\hline & SD & 0.69 & 0.82 \\
\hline & Meaning & Moderate & Moderate \\
\hline \multirow[t]{3}{*}{ Cognitive Strategy } & Mean $(\overline{\bar{X}})$ & 3.73 & 3.95 \\
\hline & SD & 0.62 & 0.55 \\
\hline & Meaning & High & High \\
\hline \multirow[t]{3}{*}{ Compensation Strategy } & Mean $(\overline{\mathrm{X}})$ & 3.93 & 3.71 \\
\hline & SD & 0.57 & 0.53 \\
\hline & Meaning & High & High \\
\hline \multirow[t]{3}{*}{ Metacognitive Strategy } & Mean $(\overline{\bar{X}})$ & 3.81 & 3.53 \\
\hline & SD & 0.62 & 0.74 \\
\hline & Meaning & High & High \\
\hline \multirow[t]{3}{*}{ Affective Strategy } & Mean $(\overline{\bar{X}})$ & 3.12 & 2.80 \\
\hline & SD & 0.67 & 0.78 \\
\hline & Meaning & Moderate & Moderate \\
\hline \multirow[t]{3}{*}{ Social Strategy } & Mean $(\overline{\mathrm{X}})$ & 3.50 & 3.70 \\
\hline & SD & 0.74 & 0.86 \\
\hline & Meaning & High & High \\
\hline \multirow[t]{3}{*}{ Total } & Mean $(\overline{\bar{X}})$ & 3.58 & 3.42 \\
\hline & SD & 0.46 & 0.49 \\
\hline & Meaning & High & High \\
\hline
\end{tabular}


Table 2 illustrates the findings of language learning strategies used by the Thai EFL learners in Thai public school and international school. It indicates that the language learning strategies use is at the high level with the grand mean of 3.58 and SD of 0.46 for Thai public school students and with the grand mean of 3.42 and SD of 0.49 for international school students mentioned earlier. Additionally, the results revealed that the participants in the Thai public school employ compensation strategy as the highest proportion $(\overline{\mathrm{X}}=3.93, \mathrm{SD}=0.57)$. The metacognitive strategy $(\overline{\mathrm{X}}=3.81, \mathrm{SD}=0.62)$ and the cognitive strategy $(\overline{\mathrm{X}}=3.73, \mathrm{SD}=0.62)$ are used as the high level as well. Also, the memory strategy $(\overline{\mathrm{X}}=3.36, \mathrm{SD}=0.69)$ and the affective strategy $(\overline{\mathrm{X}}=3.12, \mathrm{SD}=$ $0.67)$ are used at the moderate level.

The results, in contrast, exhibit that the participants in international school use cognitive strategy in the largest proportion $(\overline{\mathrm{X}}=3.95, \mathrm{SD}=0.55)$. The compensation strategy $(\overline{\mathrm{X}}$ $=3.71$, SD 0.53$)$, the social strategy $(\bar{X}=3.70$, SD 0.86$)$, and the metacognitive strategy $(\overline{\mathrm{X}}=3.53, \mathrm{SD} 0.74)$ are frequently used at the high level respectively. In contrast, the Thai EFL learners in international school use the memory strategy $(\overline{\mathrm{X}}=2.83, \mathrm{SD}=$ $0.82)$ and the affective strategy $(\overline{\mathrm{X}}=2.80, \mathrm{SD}=0.78)$ at the moderate level.

According to the interview data, the participants in the study have different ways to use English. Generally, English is very important for them and it is worth to study this language. It is obviously seen that many applicable methods; such as reading with pleasure, using another word and gesture to describe the unknown word, and etc, are employed by the learners to encourage their learning process and also to overcome their learning difficulties. Therefore, each learners will learn English more effectively if they know how to learn and how to apply the learning methods which are suitable for individuals.

\section{DISCUSSION}

Although the motivation component was on average at the high level among Thai EFL learners in Thai public school, it was at the moderate level among Thai EFL learners in the international school. This may be due to the different environment for learning English. As the international school requires the students to use English at all times, the teachers are all native speakers, and the peers almost always speak in English; this enables the students to use English language automatically. In addition, as the participants in this study were from the tutorial school in Bangkok due to the convenient sampling method, it affects the result of learner autonomy level of them. Obviously, there are high competition in Bangkok and most students have to learn after school more often than the students in others provinces in Thailand, the autonomy level therefore is high respectively.

According to the high learner autonomy level, it relates to how they learn language and manipulate their learning process. The results of English learning strategies use among Thai EFL learners in both international school and Thai public school were different. The finding that Thai EFL learners in international school use mostly cognitive strategy is in line with what White (1995) and Samaie et al (2015) have found. White (1995) conducted research to investigate the different use of LLS among distant learners and in- 
class learners. White found that the distant learners who claimed to have higher selfmanagement and learner autonomy level used metacognitive and cognitive learning strategies more them in-class learners did. Moreover, Samaie et al (2015) examined Iranian EFL students and found that cognitive strategies were commonly used by the participants which was mostly correlated with their autonomous level such as practicing, repeating, reviewing, translating, reasoning, and analyzing the language, and strategy use was in relation to their learner autonomy level.

In contrast, the findings of how Thai students in the Thai public school use language learning strategies is in conflict with Sumamarnkul (2006), Tirabulkul (2005), Phantharakphong (2009), Lamatya (2010), Thangpatipan (2014), Qing (2013), and Saengaroon (2015). They all found that Thai EFL learners in the Thai public school use metacognitive strategy the most while this present study found that the participants in Thai public school use compensation strategy at the highest level.

Surprisingly, this result does not concord with any previous studies which have examined the learning strategies use among Thai school students. However, there was a study by Liu (2015) which investigated Taiwan students. Liu found that the most frequent learning strategies that the participants used were compensation strategies. They employed the compensation strategies in order to fulfil the knowledge they had missed. This is in line what this study has found. In the Liu study, the participants were Taiwanese who are similar to the participants of this recent study as they are the EFL learners. The similar context of EFL learners who are Taiwanese or Thai students enables language learners to similarly attempt to find the compensation knowledge when using a foreign language like English. So, it can be said that Thai students in Thai public school would like to compensate and replace their English word or phrases with others one when they do not know how to say in the exact word.

According to the differences of language learning strategies use, it reflects the process of their learning, both inside and outside the school. The result of LLSs use by the international school students can reflect the way they have been taught. Due to the highest use of cognitive strategy, it reflects on how they create their way of learning such as, practicing, analysing and reasoning deductively, transferring the idea, summarizing the lesson, and highlighting the necessity. As the international curriculum requires the students to think on their own path rather than leading them in a limited way of learning, this encouraged the students to consider about their learning process. The other strategies use among the international school students was also high, especially use of compensation, social, and metacognitive strategies. They used direct strategies rather than the indirect ones as it directly affected their language learning process.

On the one hand, Thai public school students acquired mostly compensation strategy as they have not so much chance for English language interaction as the international school students have. So their proficiency in use of English naturally may be less than those who study using English all the time. However, it is interesting to see some more specific strategies that our participants employed in order to learn English. Our research could be used to help teachers think of new ways to teach their students learning 
strategies, or possibly show their students some new techniques to help them become more proficient in English.

Moreover, in terms of maintaining the use of language learning strategies, the language teachers should also accustom their students to these strategies in order to enable them to use the strategies automatically when learning language. It is obviously seen that language learning strategies can pave the way for the students to be lifelong learners because they know how to learn. This concept also matches how learner autonomy works. So, with the suitable methods, the students can pave their own way of learning and eventually become autonomous learners.

Furthermore, in view of the teaching material design and tasks, the different result of learning strategies use among the students in both types of school presented in this study suggests the language teachers should design their materials and tasks to fulfil what the students lack. The findings of this study showed a high level of learner autonomy among the Thai students in Thai public schools. This suggests a change of the teaching method of Thai teachers. Many approaches provided by technological advance have helped the teachers to improve the materials and the resources for the students. The result of previous studies have shown that metacognitive strategies are used mostly among Thai learners; however, in this study, Thai learners in the Thai public school employed mostly compensation strategies. This can lead to the implementation of other strategies which can support each other. Finally, the students will achieve their potential in language learning by acquiring suitable strategies of their own.

\section{CONCLUSION}

From the results showing learner autonomy levels among Thai EFL learners in both international school and Thai public school, this reflects the teaching and school curriculum may promote the students to rely more on themselves. This study has shown that Thai EFL learners are autonomous as the Mean and the Standard Deviation from the findings are high. Although it is known that the Thai educational curriculum may not promote learner autonomy as much as the international curriculum, the findings of this study was different. Thai EFL learners in the Thai public school were ready to be autonomous learners. However, it might be that the participants in this study were in the tutorial school, so their learner autonomy may be higher because of the learners themselves, not from the curriculum.

With regard to the result of language learning strategies investigation among the autonomous learners, it revealed that a high proportion of LLS are used among Thai students, both in international school and Thai public school. In terms of teaching method, it is great for EFL teachers to consider the language learning strategies and teach their students the strategies appropriate to their proficiency. It is also great to encourage the students attempting to use all of the strategies as it can promote selfconfidence and positive motivation to the students, such as affective strategies can help the learners coping with difficulties and push them onwards. 


\section{REFERENCES}

Benson, P. (2011). Teaching and researching autonomy. New York: Longman/Pearson.

Borg, S. (2012). Learner autonomy: English language teachers' beliefs and practices. British Council.

Chamot, A. U. (1987). The learning strategies of ESL students. In A. Wenden, \& J. Rubin (Eds.), Learner strategies for second language acquisition (pp.71-83). Prentice Hall: Englewood Cliffs.

Gardner, H. (1981). Frames of mind: The theory of multiple intelligences. NY: Basic.

Lamatya, Y. (2010). A study of English language learning strategies of M.5 students with different English achievement. Bangkok: Thammasat University.

Lightbown, P. M., \& Spada, N. (2013). How languages are learned. Oxford: Oxford U.

Little, D. (1991) Learner autonomy 1: Definitions, issues, and problems. Dublin: Authentic.

Little, D. (1994). Autonomy in language learning: Some theoretical and practical considerations. In A. Swarbrick (Ed.), Teaching modern languages (pp. 81-87). Routledge.

Littlewood, W. (1996). Autonomy: An anatomy and a framework. System, 24, 427-435.

Liu, H. J. (2015). Learner autonomy: The role of motivation in foreign language learning. Journal of Language Teaching and Research, 6, 1165-1174.

Malley, J., \& Chamot, A. (1990). Learning strategies in second language acquisition. New York: Cambridge University Press.

Mitchell, D. (2014). What really works in special and inclusive education: using evidence-based teaching strategies? New York: Routledge.

Oxford, R. L. (1990). Language learning strategies: What every teacher should know? New York: Newbury House/Harper Collins.

Oxford, R. L. (2003). Toward a more systematic model of L2 learner autonomy. In D. Palfreyman, \& R. Smith (Eds.), Learner autonomy across cultures: language education perspectives (pp. 75-91). New York: Palgrave Macmillan.

Oxford, R. L. (2017). Teaching and researching language learning strategies: selfregulation in context. New York, N.Y: Routledge. 
Phantharakphong, P. (2009). Language learning strategies used by good and poor high school students at Chiang Yuen Pitthayakhom School in Mahasarakham. Bangkok, Thailand: Language Institution, Thammasat University.

Qing, Y. Y. (2013). A survey study of language learning strategies used by EFL learners at Santirat Wittayalai School in Bangkok. Bangkok, Thailand: Thammasat U.

Rubin, J. (1987). Learner strategies: Theoretical assumptions, research history and typology. In A. Wenden, \& J. Rubin (Eds.), Learner strategies in language learning, (pp. 15-30). Hertfordshire: Prentice Hall.

Saengaroon, J. (2015). Gender and English language learning strategies of undergraduate at Rajamangala University of Technology Lanna Tak. Bangkok, Thailand: Language Institute, Thammasat University.

Samaie, M. et al (2015). On the relationship between learner autonomy and language learning strategies among Iranian EFL students. Int. J. of Edu. Inves., 2(6), 96-109.

Scharle, A., \& Szabó, A. (2000). Learner autonomy: a guide to developing learner responsibility. Cambridge New York: Cambridge University Press.

Sumamarnkul, W. (2006). A survey study on L2 learning strategy of science and technology students at Thammasat University. Bangkok, Thailand: Thammasat U.

Swatevacharkul, R. (2008). An investigation on readiness for learner autonomy, approaches to learning of tertiary students and the roles of English language teachers in enhancing learner autonomy in higher education. Bangkok: Dhurakijpundit U.

Tarone, E. (1980). Communication strategies, foreign talk, and repair in interlanguage. Language Learning, 30, 417-428.

Tayjasanant, C., \& Suraratdecha, S. (2016). Thai EFL teachers and learners' beliefs and readiness for autonomous learning. The SE. Asi. J. of Eng. Lang. Stu., 22(3), 153-169.

Thangpatipan, K. (2014). A survey study of language learning strategies use by Thai high school students in an English program. Bangkok, Thailand: Thammasat U.

Tirabulkul, N. (2005). A study of language learning strategies of students in the MA program for the TEFL program, Thammasat University. Bangkok: Thammasat U.

Wenden, A. (1991). Learner strategies for learner autonomy: planning and implementing learner training for language learners. New York: Prentice.

Wenden, A., \& Rubin, J. (1987). Learner strategies in language learning. Englewood Cliffs, NY: Prentice/Hall International.

White, C. (1995). Autonomy and strategy use in distance foreign language learning: research findings. System, 23(2), 207-221. 
Wong, M. S.-L. (2005). Language learning strategies and language self-efficiency.

Rational Language Centre Journal, 36(3), 245-269. 